\title{
TUŠČIOJO TURKIABALNIO SINDROMAS: ETIOLOGIJA, PATOGENEZE், DIAGNOSTIKA IR GYDYMAS
}

\author{
Asta Mozūrè \\ Vilniaus universiteto Medicinos fakultetas
}

Raktažodžiai: tuščias turkiabalnis, pneumoencefalografija, hipofizès apopleksija.

\begin{abstract}
Santrauka
Tuščiojo turkiabalnio sindromas yra subarachnoidinio tarpo išvarža ị turkiabalnị, kitaip dar vadinama arachnoidocelè. Ji dažnai būna atsitiktinis radinys MRT vaizduose. Tyrimo tikslas - aprašyti tuščiojo turkiabalnio sindromą, aptarti jo etiologiją, atsiradimo mechanizmus, simptomatiką, diagnostikos ir gydymo galimybes. Mokslinių darbu paieška atlikta PubMed, Google Scolar duomenų bazėse. Neįtraukti straipsniai, parašyti kita nei anglų kalba, atmesti ne viso teksto straipsniai, bei tie, kurių turinys neatspindejo analizuojamos temos. Tyrimo rezultatai parodè, kad šis sindromas dažnai asimptomis, tačiau kartais sukelia nespecifinius simptomus (galvos skausmą, regos sutrikimą, rinorėją). Galima hiperprolaktinemija arba hormonų trūkumas iki hipopituitarizmo. Kol kas nèra visuotinai priimtų tuščiojo turkiabalnio sindromo diagnostikos ir gydymo gairių, o antrinio tuščiojo turkiabalnio diagnostika, gydymas bei patogenezès mechanizmai apsiriboja tik klinikinių atvejų aprašymais. Šio sindromo vienas pagrindinių diagnostikos metodų yra magnetinio branduolių rezonanso tyrimas.
\end{abstract}

\section{Ivadas}

Tuščiojo turkiabalnio sindromas (TTS) - tai subarachnoidinio tarpo išvarža ị turkiabalnị, kitaip dar vadinama arachnoidocelè, kuri suspaudžia ir išlygina hipofizę ir išplečia bei suspaudžia hipofizès kotelị. Terminas „tuščiasis turkiabalnis" apibūdina radiologinị hipofizès srities vaizdą, kai kompiterinès tomografijos (KT) ar magnetinio branduolinio rezonanso (MRT) vaizduose matomas sumažèjęs hipofizès tūris. TTS gali būti tiek pirminis, dèl turkiabalnio diafragmos defekto, subarachnoidinès išvaržos, tiek dažniau pasitaikantis antrinis dèl radioterapijos, medikamentų, chirurgijos - gydant hipofizès adenomas, apopleksiją, posmegeninès liaukos hemoragijas (Sheehano sindromą), infarkta ar ne- krozę, galvos traumas, hipofizès uždegimą, infekciją, didelius intrakranijinius navikus [1,2].

Tyrimo tikslas - aprašyti tuščiojo turkiabalnio sindromą. Aptarti jo etiologiją, atsiradimo mechanizmus, simptomatiką, diagnostikos ir gydymo galimybes.

\section{Tyrimo medžiaga ir metodai}

Mokslinių darbų paieška atlikta naudojant kompiuterines mokslinių darbų bazes PubMed, Google Scolar. Neįtraukiami buvo straipsniai, parašyti kita nei anglų kalba, atmesti ne viso teksto straipsniai, bei tie, kurių turinys neatspindejjo analizuojamos temos.

\section{Tyrimo rezultatai}

Patogenezė. Pirminis tuščiojo turkiabalnio sindromas gali išsivystyti dèl tokių priežasčiu kaip padidèjęs intrakranijinis spaudimas ir turkiabalnio diafragmos defektas. Tarp rizikos veiksnių esti arterinè hipertenzija, nutukimas, miego apnèja, nëštumas. Antrinio tuščiojo turkiabalnio sindromo rizikos veiksniai yra medikamentinis, chirurginis adenomų gydymas, hipofizès apopleksija, igimtas hipopituitarizmas, radiacija, Sheehan sindromas, smegenų trauma. Turkiabalnio dydžio pokyčiai, konkrečiai, padidejimas, turi nemažai įtakos TTS susiformavimui [2,3].

Turkiabalnio diafragma - tai kietojo smegenų dangalo ịlinkimas, atskiriantis kryžmès cisterną nuo turkiabalnio. Kai yra diafragmos defektas arba hipofizès tūrio sumažèjimas ir padidèjęs intrakranijinis spaudimas, subarachnoidinis tarpas gali išsiveržti ị turkiabalnị ir suformuoti subarachnoidinio tarpo išvaržą (vaizdo tyrimuose matomas tuščiasis turkiabalnis). I turkiabalni gali įsiveržti ir optinè kryžmè, sukelianti regejjimo sutrikimus, bei priekinis 3 skilvelis. Kai cerebrospinalinis skystis pateka ị turkiabalnị, jis sukelia hipofizès suplokštėjimą, sumažèjimą, spaudimą. Kartu patempiama ir pritraukiama hipofizès kojelè, todèl gali išsivystyti hipopituitarizmas ar kitų hipofizès hormonų sumažejimas arba hiperprolaktinemija.

Cerebrospinalinis skystis (CSS) gali praardyti pleišta- 
kaulị, įsiveržti ị pleištakaulio sinusą ir sukelti skysčio tekèjimą iš nosies (rinorèją). Patogenezèje svarbus nėštumas, nes hipofizè padideja, padidindama ir turkiabalnị, o vèliau sumažeja. Taip susiformuoja tarpas cerebrospinaliniam skysčiui nutekèti ị turkiabalnị. Menopauzė yra kitas svarbus rizikos veiksnys TSS susiformuoti, nes tuomet vyksta hipofizès involiucija $[4,5]$.

$1955 \mathrm{~m}$. F. Foley apibūdino terminą ,gerybinè intrakranijinè hipertenzija“ (IIH), kuri pritaikè vaisingo amžiaus nutukusioms moterims. Nuo to laiko buvo nemažai svarstoma apie rizikos veiksnius, kurie sukelia intrakranijinio spaudimo padidejjimą. Vyravo bendroji nuomonè, jog intrakranijini spaudimą didina nutukimas, kvèpavimo sutrikimas, hipoventiliacija, todèl padidejja parcialinis $\mathrm{CO} 2$ (pCO2). Kai šie pacientai turi ir turkiabalnio diafragmos defektą, vyksta turkiabalnio remodeliacija ir padidejjimas. Kitas svarbus turkiabalnio struktūrinių pokyčių mechanizmas apibūdintas kaip erozija - tai turkiabalnio kietosios plokštelès (lamina dura) praradimas [6].

Idiopatinè ar gerybinè intrakranijinè hipertenzija (arba pseudotumor cerebri) yra sindromas, kuris pasireiškia padidejjusio intrakranijinio spaudimo simptomatika, nesant struktūrinių smegenų pokyčių. IIH priežastis dar nèra galutinai išaiškinta, tačiau didelį vaidmenį atlieka nutukimas. Egzistuoja ir tam tikros teorijos, aiškinančios intrakranijinio spaudimo padidejjimą. Priežastys apima sumažejusią ar padidèjusią CSS produkciją arba sumažejusią rezorbciją. Egzistuoja sąsajos su vitaminu A, kai kuriais medikamentais, tam tikromis ligomis [7-9]. Tarp kitų priežasčių, didinančių intrakranijinị slègi, yra smegenų tumoras, intrakranijinè trombozè, hidrocefalija [1].

Idiopatinè intrakranijinè hipertenzija didžia dalimi susijusi su šoninio sinuso stenoze, tačiau stenozè gali pasireikšti ir pulsuojančiu spengimu ausyse, nesant intrankranijinès hipertenzijos. Buvo atliktas retrospektyvinis tyrimas, kuris sieke pagrịsti hipotezę, jog tuščias turkiabalnis susijęs ne su intrakranijinio spaudimo padidejjimu, o su šoninio sinuso stenoze. Gauti rezultatai, jog pacientų, kuriems atlikta veninio stentavimo operacija (dèl veninio sinuso stenozès), buvo žymiai didesnis turkiabalnio tūris, nei kontrolinejje grupeje. Nebuvo rasta turkiabalnio tūrio ar aukščio skirtumų tarp IIH ir pulsuojančio spengimo ausyse be IIH grupių. Šie rezultatai patvirtino tyrimo hipotezę, tačiau reikalingi tolesni šios srities tyrimai [10].

Aprašyta atvejų, kai tuščias turkiabalnis susiformavo dèl adenomu gydymo, pvz., makroprolaktinomos gydymo dopamino agonistais. Veikiama šių vaistų, prolaktinoma greitai traukiasi, sudarydama sąlygas cerebrospinaliniam skysčiui tekèti ị turkiabalnị [11].
Klinika. TTS dažniausiai būna asimptomis, randamas atsitiktinai atliekant hipofizès MRT ar KT dèl kitų priežasčių, ypač kalbant apie pirminį tuščiajị turkiabalnị. Dažniausiai simptomai nespecifiniai, todèl sunku įtarti TTS. Dažniausias iš simptomų yra lètinis galvos skausmas, regos sutrikimas, retai pasitaiko rinorèja (cerebrospinalinio skyčio tekejjimas iš nosies), intrakranijinio spaudimo padidejjimas, optinio disko patinimas (papiledema), galvos svaigimas, lètinis nuovargis, psichoziniai simptomai. Kartais gali būti sukeliamas hipopituitarizmas, augimo hormono, gonadotropinų sumažéjimas, gali būti vėmimas, viduriavimas. Dažnai pacientai būna nutukę arba turintys antsvorio. Moterims dèl hiperprolaktinemijos gali būti nereguliarios mènesinès, galaktorèja, hipertrichozè, vyrams seksualiniai sutrikimai, ginekomastija. Gali pasireikšti necukrinio diabeto požymių: polidipsija, poliurija, hiponatremija, esant normaliam gliukozès kiekiui kraujyje $[4,12,13]$.

Diagnostika. Anksčiau TTS diagnostikai buvo naudotas pneumoencefalografijos metodas, kai liumbalinès punkcijos metu buvo pašalinama dalis cerebrospinalinio skysčio ir ji pakeičiama oru, deguonimi arba heliu. Dèl to rengenogramose geriau buvo vizualizuojamos smegenų struktūros $[6,14]$. Dabar šis metodas nebenaudojamas. Pagrindinis TTS bei vienas pagrindinių hipofizès adenomų diagnostikos metodų yra MRT ir KT tyrimai, gerai vizualizuojantys hipofizès srities struktūras. MRT tyrime matomas cerebrospinalinis skystis turkiabalnyje, suplokštejusi, pusmènulio formos hipofizè, gali būti padidejęs kaulinis turkiabalnis.

Turintiems tuščiaji turkiabalnị, rekomenduojama atlikti oftalminę echografiją ir aptikti regos nervo diametro pokyčius intrakranijinès hipertenzijos nustatymui, kadangi regos nervo diametras yra susijęs su intrakranijinio slègio pokyčiais [4]. Svarbu laiku nukreipti pacientą endokrinologo konsultacijai ir ịvertinti hipofizès sekretuojančius hormonus net ir asimptominiams pacientams, kadangi dažnai tam tikras hormonų trūkumas lieka nepastebètas ir neįvertintas [15].

Gydymas. TTS gydymui ir stebėsenai svarbi multidisciplininès komandos (endokrinologas, oftalmologas, neurochirurgas, neuroradiologas) priežiūra. Hipopituitarizmas gydomas pakaitine hormonu terapija, pradedant nuo hidrokortizono ir levotiroksino, baigiant augimo hormonu. Hiperprolaktinemija gydoma dopamino receptorių agonistais [4]. Kadangi antrinis tuščiojo turkiabalnio sindromas gali išsivystyti gydant makroprolaktinomą dopamino agonistais, siūloma sumažinti jų dozę, kad adenoma nesumažètų labai sparčiai ir nesukeltų CSS tekèjimo ị turkiabalnị. Jeigu esant antriniam TSS (pvz. dèl makroadenomos gydymo) yra ir regos blogejjimas bei MRT vaizduose matomas regejjimo trakto tempimas, galima atlikti chiazmapeksiją [16]. Kitas ryškaus regèjimo pablogèjimo gydymo metodas yra lum- 
boperitoninis šuntas. Nors jis taikomas retai, tačiau aprašytas atvejis, kai šis metodas smarkiai pagerino regejjimo funkciją [17]. Intrakranijnès hipertenzijos gydymui rekomenduojamas svorio mažinimas (dieta ir bariatrinè chirurgija) bei osmosiniai diuretikai, dažniausiai acetazalomidas. Esant rinorejai, atliekama peritoninè ventrikulinè operacija [4].

\section{Išvados}

1. Tuščiojo turkiabalnio sindromas dažnai nėra vien tik atsitiktinis radinys MRT vaizduose.

2. Anksčiau buvo manyta, jog asimptomiams pacientams, turintiems TTS, atidesne priežiūra, ištyrimas ar gydymas nereikalingi, dabar daugeja tyrimų, remiančių nuostatą, jog net ir nesant simptomų, svarbu atlikti išsamų paciento ištyrimą, pasitelkiant daugiadisciplininę komandą.

3. Kol kas nèra visuotinai priimtų tuščiojo turkiabalnio sindromo diagnostikos ir gydymo gairių, o antrinio tuščiojo turkiabalnio diagnostika, gydymas bei patogenezès mechanizmai apsiriboja tik klinikinių atvejų aprašymais.

\section{Literatūra}

1. Ucciferro P, Anastasopoulou C. Empty sella. Treasure Island (FL): StatPearls Publishing 2020. http://www.ncbi.nlm.nih. gov/books/NBK541002/

2. Miljic D, Pekic S, Popovic V. Empty sella. Endotext. South Dartmouth (MA): MDText. com, Inc. 2000. http://www.ncbi. nlm.nih.gov/books/NBK532084/

3. Fouad W. Review of empty sella syndrome and its surgical management. Alexandria Journal Medicine 2011; 47(2):139-47. https://doi.org/10.1016/j.ajme.2011.06.005

4. Chiloiro S, Giampietro A, Bianchi A, Tartaglione T, Capobianco A, Anile C. Diagnosis of endocrine disease: primary empty sella: a comprehensive review. European Journal Endocrinology 2017;177(6):R275-85.

https://doi.org/10.1530/EJE-17-0505

5. Anderson JR, Antoun N, Burnet N, Chatterjee K, Edwards O, Pickard JD. Neurology of the pituitary gland. Journal Neurology, Neurosurgery Psychiatry 1999; 66(6):703-21.

https://doi.org/10.1136/jnnp.66.6.703

6. Kaufman B. The "empty" sella turcica-a manifestation of the intrasellar subarachnoid space. Radiology 1968;90(5):931-41. https://doi.org/10.1148/90.5.931

7. Boyter E. Idiopathic intracranial hypertension. Journal American Academy Physician Assistants 2019;32(5):30-5. https://doi.org/10.1097/01.JAA.0000554732.85914.91

8. Mondragon J, Klovenski V. Pseudotumor cerebri. Treasure Island (FL): StatPearls Publishing 2020. http://www.ncbi.nlm.nih.gov/ books/NBK536924/

9. Burkett JG, Ailani J. An Up to Date review of pseudotumor cerebri syndrome. Current Neurology Neuroscience Reports 2018;18(6):33.

https://doi.org/10.1007/s11910-018-0839-1
10. Zetchi A, Labeyrie M-A, Nicolini E, Fantoni M, Eliezer M, Houdart E. Empty sella is a sign of symptomatic lateral sinus stenosis and not intracranial hypertension. American Journal Neuroradiology 2019;40(10):1695-700.

https://doi.org/10.3174/ajnr.A6210

11. Cobb MI-PH, Crowson M, Mintz-Cole R, Husain AM, Berger M, Jang D. Transnasal transsphenoidal elevation of optic chiasm in secondary empty sella syndrome following prolactinoma treatment. World Neurosurgery 2018;112:250-3.

https://doi.org/10.1016/j.wneu.2018.01.202

12. Rani PR, Maheshwari R, Reddy TSK, Prasad NR, Reddy PA. Study of prevalence of endocrine abnormalities in primary empty sella. Indian Journal Endocrinology Metabolism 2013;17(Supp11):S125-6.

https://doi.org/10.4103/2230-8210.119527

13. Nwafor C, Akhigbe A. Diverse clinical manifestations of empty sella syndrome: an imaging based study. Saudi Journal Health Sciences 2019;8. https://doi.org/10.4103/sjhs.sjhs_122_19

14. Allely CS, Hadjikhani N, Toro R, Gillberg C. Neuropsychiatry. Brain Mapping. Elsevier 2015; 1049-60. https://doi.org/10.1016/B978-0-12-397025-1.00131-7

15. Ekhzaimy AA, Mujammami M, Tharkar S, Alansary MA, Al Otaibi D. Clinical presentation, evaluation and case management of primary empty sella syndrome: a retrospective analysis of 10-year single-center patient data. BMC Endocrine Disorders 2020;20(1):142.

https://doi.org/10.1186/s12902-020-00621-5

16. Graillon T, Passeri T, Boucekine M, Meyer M, Abritti R, Bernat A-L, et al. Chiasmapexy for secondary empty sella syndrome: diagnostic and therapeutic considerations. Pituitary 2021;24(2):292-301.

https://doi.org/10.1007/s11102-020-01104-5

17. Nizamani W, Siddiqui M, Nizar Ali Momin S, Waqas M, Jooma R. Resolution of symptomatic secondary empty sella syndrome following lumbar-peritoneal shunt. Surgical Neurology International;9:72.

https://doi.org/10.4103/sni.sni_267_17

\section{EMPTY SELLA SYNDROME, ETIOLOGY, PATHOGENESIS, DIAGNOSIS AND TREATMENT A. Mozūrè}

Keywords: Empty sella, Pneumoencephalography, Pituitary apoplexy.

Summary

Empty sella syndrome is a herniation of the subarachnoid space into the sella, otherwise known as the arachnoidocele. It is often a random finding in MRI images. This syndrome is often asymptomatic, but sometimes differs in nonspecific symptoms (headache, visual disturbances, rhinorrhea), possible hyperprolactinemia, or hormon deficiency and hypopituitarism. One of the main diagnostic methods is magnetic resonance imaging.

Correspondence to: asta529@gmail.com

Gauta 2021-05-03 